\title{
The wager of faith in fiction and psychoanalysis: reading Colm Tóibín's The Testament of Mary.
}

'Faith makes us, and not we it; and faith makes its own forms'. Ralph Waldo Emerson (1850).

\begin{abstract}
Colm Tóibín's novella The Testament of Mary offers a provocative re-imagining of the Virgin Mary's life twenty years after the crucifixion of her son Jesus. Drawing on Richard Kearney's (2010) notion of anatheism or a 'return to God after God', I use the fictive space opened up Tóibín's version of the Gospel as a spur to understanding the way in which faith may be conceived of as wager within both fiction and psychoanalysis. After discussing this in relation to themes of hospitality and alterity, I attempt to explore the annunciatory potential of the creative work of art and its significance for understanding alterity within psychoanalysis. I go on to illustrate the existential nature of the psychoanalytic wager of faith with reference to Winnicott's (1971) paper 'The Use of an Object', concluding with a brief discussion of the significance of testimony within psychoanalytic work.
\end{abstract}

\section{Introduction}

Climbing the north staircase to the friars' cells in the $15^{\text {th }}$-century Dominican convent of San Marco in Florence, what seems at first to be a distant cloud of Mediterranean pinks, sepias and lustrous gold only gradually comes into focus. It is a scene at once familiar and extraordinary. The Annunciation, painted by Fra Angelico in 1450, is carefully positioned at the top of the stairs, allowing us to pause for a moment before the life-sized image depicting the Archangel Gabriel visiting the Virgin Mary to tell her that she is about to conceive the Son of God. Mary, dressed in her customary blue, is sitting modestly on a simple, wooden stool in a cloister with her hands crossed over her breast. Her head is bending reverently towards her radiant visitor whose magnificent, gleaming, multicolour wings announce his celestial status as emissary from God. Mary seems surprisingly calm and serene. Her gaze, focused on Gabriel's eyes, gives little hint of surprise at being the recipient of such unexpected news. However, we might choose to read in the slight inclination of her body towards the angel, as if she is listening to words she cannot quite believe, a moment of hesitation as the full realisation of her divine duty becomes borne upon her. Of course, we know from St. Luke that Mary chose to accept her role as Mother of the Son of God, responding to the angel in the beautiful words of the Gospel: 'Behold the handmaid of the Lord. May it be done unto me according to thy Word'.

The frescoes at San Marco have been studied extensively by art historians, with numerous scholarly works (eg. Hood, 1993; Lloyd, 1998) documenting the power, subtlety and influence of Fra Angelico's artistic and religious imagination. But by the time he was commissioned by Cosimo de' Medici to decorate the newly-established convent of San Marco, Fra Angelico had already painted two different versions of the Annunciation. As Hodge (2006) points out, this particular fresco unusually lacks many of the symbols that were traditionally used to suggest the sanctity of the Virgin Mary. There are no white lilies to convey her virginity, nor does Gabriel appear to be interrupting her reading of the scriptures, a common artistic device used to index Mary's piety. Indeed, unlike his previous, more elaborate and colourful paintings of the same scene, Fra Angelico seems to have made a deliberate decision to keep this version of the Annunciation as simple and spare as possible. 
We do not know the reason for this; but given the fresco's central position in the convent, perhaps we might imagine that he wanted to allow his fellow friars maximum creative freedom to fill in the details themselves of what would have been a very familiar story; and to use the simplicity of the fresco as artistic inspiration for prayer, meditation and the practice of their faith.

There can be few scenes from the Bible more frequently represented within Christian iconography than the Annunciation. That so many versions of Mary have appeared over the centuries is testament to not only to the imaginative appeal that she holds as Theotokos, or God-bearer, but also to the dearth of information we have about the life of this teenage mother from Nazareth. Of course, biography was not the concern of New Testament writers, who were interested simply in demonstrating the fulfilment of Old Testament prophecies. Nonetheless, as Warner (2000) points out, the absence of details about Mary's life in the bible is a lacuna that has come to be filled with an accretion of myths and stories that makes her a figure 'that has been formed and animated by different people for different reasons and is truly a popular creation' (p. xxiv). All we do know, according to Christian theology and the work of artists such as Fra Angelico, is that there was a primal moment symbolised by her encounter with the angel where Mary was asked to make a choice. Faced with the angel and filled with doubt - St Luke tells us that Mary was 'perplexed' by the angel's words - she nonetheless assents to her sacred duty: 'may it be done unto me'. It is a courageous act of faith, in which she commits herself to the Holy Spirit and thereby becomes receptacle of the divine. Richard Kearney (2010) calls this decisive instant the 'wager of faith': where we respond to the Stranger with either hospitality or hostility; where we accept or refuse the advent of the sacred. It is the inaugural encounter with the other that sponsors the choice of faith.

It is to this moment of wager that Colm Tóibin's provocatively-titled The Testament of Mary returns us. In this brief, lyrical novella, also staged as a play, Tóibín offers a moving first-person account of the grieving Mary's life in exile in Ephesus, twenty years after the crucifixion of her son. However, this newly-imagined voice of Mary has been seen by some as shocking, with both book and play deemed to be a blasphemous reworking of a sacred truth. The play's opening on Broadway was marked by Catholic demonstrations denouncing it as "not only blasphemous but heretical. It presents a caricature of the Blessed Virgin Mary and implicitly denies all of the dogmas the Church has defined in her regard." (Los Angeles Times, March 2013). Fictional re-workings of texts deemed to be sacred are of course scarcely new. They rarely receive unanimous praise and on occasions have been known to provoke violence. One of Tóibín's best known predecessors, Salman Rushdie's The Satanic Verses (1988), resulted in the Ayatollah Khomeini's fatwa in which he called for Muslims to kill Rushdie and his publishers. Philip Pullman's more recent trilogy His Dark Materials, too, was roundly condemned by the powerful US-based Catholic League which campaigned successfully against the film version The Golden Compass, declaring it promoted atheism. Against this backdrop of wounded belief systems and book-burning outrage, it would be all too easy to read Tóibín's novella simply as a kind of anti-Catholic political thriller in which a young rebel is transformed into a god via a band of misfit friends, hysterical fans and susceptible followers. I think this would be to miss the point of this artful and intensely thought-provoking book. For by inviting the reader to believe his fictional account of Mary's life alongside an imaginative reconstruction of how her role as Mother of Jesus came to be written, I think Tóibín sets out to achieve two crucial and interrelated aims: first, to call the authority of texts normally held as sacred into question; and second, to thereby open up a space in which our traditional credos can be re-constituted or salvaged in the light of imagined alternatives. 
The power of Tóibín's tale rests on his ability to create and sustain this fictive space in which a wager of faith becomes a vivid reality for the reader and constitutes the fulcrum on which his entire novella turns. In his re-imagining of a Mary who stubbornly refuses to believe that her son is the Son of God, Tóibín raises questions about the basis on which we have come to be inhabited by the story of that inner presence of the other deemed to be divine. However, the reception of otherness whose inner presence is constitutive of subjectivity, if not divinity, is equally a central preoccupation for psychoanalysis; and so in this paper, I want to suggest that the way in which Tóibín tells his story may have something to offer how we understand the notion of faith in psychoanalytic theory and practice. In setting out my thesis in this way, however, I must first recognise that the relationship between faith and psychoanalysis is almost as troubled as the relationship that exists between literature and psychoanalysis and may in fact have much in common with it. For just as psychoanalysis has traditionally attempted to subsume the field of literature in what Felman (1977) has called a 'fight for recognition' (p. 5), so too has psychoanalysis chosen in the past to claim priority over religion by emphasising its defensive function within the psyche. In 'The Future of an Illusion', Freud (1927) claimed that all aspects of religious life were 'illusions, fulfilments of the oldest, strongest and most urgent wishes of mankind' (p. 30) and that giving up our infantile need for the protection of an all-powerful father was the mark of emotional maturity. If, as Rieff (1966) points out, 'Freud has systemised our unbelief' (p. 40), it is scarcely surprising that the concept of faith has since struggled to find a foothold within psychoanalytic theory, despite Bion's (1970) call for analysts to approach their work in a state of 'faith that there is an ultimate reality and truth' (p.31). More recently, however, there seems to have been what Starr (2008) calls a 'gradual rapprochement' between the two fields of study, where a cultural shift away from compliance with traditional religious doctrine towards respect for the individual's own inner spiritual orientation has allowed both religion and psychoanalysis to acknowledge the role faith may play in psychic change and transformation. Contemporary psychoanalysts such as Eigen, (1999), Ghent (1999), Neri (2005), Safran (1999, 2006), Sorenson (2004) and Spezzano and Gargioulo (1997), amongst others, have integrated their theological interests with psychoanalytic theory alongside religious scholars such as Ostow (1995) and Zornberg $(1995,2002)$, writers who have drawn from psychoanalysis in their understanding of religious belief.

In writing this paper, I have been mindful of the need to tread softly on territory that extends well beyond my usual academic and psychoanalytic comfort zone. It will be apparent to readers, for example, that I am not qualified to approach my topic from the perspective of theological scholarship; nor indeed can I claim any expertise in the history of art. My aim is somewhat less ambitious, and rests on a willingness to cross disciplinary divides in order to bring imaginative ideas from the domains of fiction and postmodern theology within the purview of existing psychoanalytic thinking. Such cross-fertilisation carries certain risks, yet I believe offers the potential for fresh insights and different ways of thinking that can refresh ideas and concepts that have become familiar over time. More specifically, I will use the illusory space of fiction that Tóibín opens up in The Testament of Mary as provocative spur to understanding the way in which faith may be conceived of as wager within both fiction and psychoanalysis. Developing my topic via Kearney's (2010) notion of anatheism as well as through a discussion of hospitality and alterity, I will briefly draw on Winnicott's (1971) paper 'The Use of an Object' to illustrate the existential nature of the psychoanalytic wager of faith. The paper concludes with a discussion of the relevance of testimony within psychoanalytic work. 


\section{The Testament of Mary.}

Tóibín sets his story within a story, situating Mary as necessary participant in as well as critical witness to the creation of a narrative that was to become central to Christian identity: the life and suffering of her son Jesus. We meet her when she is living in exile in Ephesus, twenty years after the violent death of her son. Now an elderly woman, traumatised by what she has seen and wracked by painful memories, Mary is tortured by her failure to save Jesus from his fate. She is guarded by two disciples of Jesus who are engaged in the onerous task of writing down a record of what happened to her son. They continually question her about the events leading up to the crucifixion, but she refuses to co-operate with the story they so clearly want to hear. For whilst Mary cannot read or write, she is all too aware that what is being written is a version of events that she does not recognise. 'I have asked him to read the words aloud to me but he will not. I know that he has written of things that neither he saw nor I saw. I know that he has also given shape to what I lived through and he witnessed, and that he has made sure that these words will matter, that they will be listened to' (p. 5). From the outset then, Tóibín's novella is purposely framed as a vindication of Mary's own testimony, offered in direct contrast to the words that will later become the basis of the New Testament.

Tóibín imagines Mary's story via a staging of three central events in the Gospels: the raising of Lazarus from the dead, the wedding at Cana where Jesus changes water into wine, and the final scenes at Calvary culminating in Jesus's crucifixion. In St. John's gospel, the miracle of the raising of Lazarus is presented at length and in detail as the final and most important sign that Jesus gives; it is this event that leads directly to the decision of Caiaphas and the Sanhedrin to kill Jesus. However, Tóibín's reworking of the story places the raising of Lazarus much earlier in the story, and is framed as an event that Mary neither witnesses nor condones. Instead, she is deeply disturbed by the notion of bringing someone back from the dead: 'no-one should tamper with the fullness that is death' (p. 31). The description of the dead Lazarus being called back into life is presented not as miraculous but rather as a truly chilling event: 'a figure dirtied with clay and covered with grave clothes wound around him began with great uncertainty to move [...]lt was as though the earth beneath him was pushing him and the letting him be still again like some strange new creature jerking and wriggling towards life' (p. 35).

Tóibín subsequently places Lazarus alongside Mary and Jesus at the wedding feast in Cana. The excitement of the guests at what has happened to Lazarus together with Jesus's presence means that Mary and her son are now both in danger of being killed by the authorities. She tries to persuade Jesus to leave the wedding, but finds to her dismay that he ignores her: 'he had begun to talk to others, high-flown talk and riddles, using strange proud terms to describe himself and his task in the world [...] I heard him saying that he was the Son of God' (p. 47). Realising that she will not be able to save Jesus, she slips away from the wedding party and returns to Nazareth. The political unease at Jesus's actions now takes on a more menacing quality and shortly after her return, she learns that her son has been taken by the Sanhedrin and is to be crucified. Mary agrees to go to Jerusalem for her own safety in the hope, too, of seeing Jesus and disguises herself to accompany the crowd to the crucifixion.

It is here that Tóibín is utterly unsparing in his detailed portrayal of a scene filled with horror, cruelty and blood. This Jesus doesn't suffer quietly or easily. He fights back; he screams with pain and 
writhes in agony as he is nailed to the cross. Mary forces herself stay and watch the dreadful, drawnout suffering of her son, steeling herself to be with him at the moment of his death. But in a startling reworking of the familiar Christian iconography of the Stabat Mater, Tóibín refuses to offer us any consolation. For here there is no grieving mother at the foot of the cross, no Pieta holding Christ's dead, mutilated body across her knees, no Mater Dolorosa. Tóibín's Mary, in the midst of trauma, grief and terror nonetheless realises with great clarity that her own life is in imminent danger; and to save herself, she slips away before Jesus dies. Twenty years on, still brimming with guilt and remorse, she finally chokes out the frightful words that she has held back for so long: 'For years I have comforted myself with the thought of how long I remained there [...] But I must say it once, I must let the words out [...] I would leave him to die alone if I had to. And that is what I did'. (p. 84).

Following the crucifixion, and on the run with her guardian and Lazarus's sister, Mary and her companion both dream of Jesus rising up from the earth along with water overflowing from a well. The dream is so powerful that Mary feels it acquires an almost tangible quality: 'what happened in our dreams took on more flesh, had more substance, than our lives when we were conscious, alert, aware' (p. 93). Indeed, it is this very tangibility - a measure of Mary's own desperate desire for her son to return from the dead - that is subsequently written into biblical history by disciples who intend to make Jesus's resurrection the linchpin of their new Christian theology.

Mary remains consumed with guilt for the rest of her life. She is constantly badgered by her guardians to tell again the details of what happened, to add further nuances that will flesh out the story they want to hear, the story that she knows is not true. She protests that 'I never saw his grave, I never washed his body'. But Mary's testament is met with determined opposition, if not outright contradiction: 'You were there,' my guide said. 'You held his body when it was taken down from the cross'. His companion nodded.' (p. 99). As readers, we know that as Mother of Sorrows, Mary will be portrayed by artists for millennia to come at the foot of the cross, weeping over the body of her dead son. But in Tóibín's version, Mary's sorrow is a private grief, born of a sense of personal guilt that not only did she fail to protect her son from a humiliating and protracted death, but that she failed to stay with him to the end.

By the end of the book, Tóibín's Mary ends her days fearing that the men who are guarding her will be the ones who 'thrive and prevail' long after she is gone. She has refused to believe in the new story being constructed around the life and death of her son, a story written by men that will form the basis of the new Christian religion stretching across the world. Instead, she takes solace in a much older story still active in Ephesus: in the maternal cult of Artemis, the many-breasted Greek virgin goddess of mythology.

\section{Faith and fiction: Kearney's 'anatheism'.}

I have wanted to offer this brief summary of Tóibín's story as a way of conveying the extent to which his novella is startling, even shocking, in its portrayal of Mary, not as Mother of God, but rather as subject in her own right. 'New Testament figures' claims Oppenheimer (2000) 'do not really have interior lives. They are mythical types'. Whilst the traditional version of Mary allows us only to think of her in her capacity as receptacle of the divine, Tóibín deliberately sets out to unsettle, disconcert and surprise us into thinking about Mary as a person, as a subject, as a woman. For those whose religious faith rests on the text that Tóibín so powerfully re-imagines, it is challenging, even perturbing, to read. 
But Tóibín is not, of course, the only writer to make the radical attempt to rework our relationship to the God of traditional theology and it could be argued that his work emerges from a contemporary and postmodern cultural recasting of 'strong' metaphysical dogma. Derrida's (1995) 'religion without religion', Caputo's (2006) notion of 'weak theology' and Kearney's (2001) return to a 'God who may be' are all concerned with subjecting the abstract, sacred, eternal, powerful God of traditional theology to doubt, re-interpretation, subjectivity and secularity. Kearney's notion of anatheism, a 'return to God after God', expresses a way of relating to the sacred in the wake of the social, cultural and intellectual 'death of God' announced by Nietzsche, Marx and Freud. As a philosophical response to our contemporary disillusionment with religion and the widespread desacralizing of the world, Kearney (2010) differentiates anatheism from dogmatic theism as well as militant atheism, refusing any absolutist positions either for or against the divine. Anatheism, proposes Kearney (2015), constitutes 'a radical opening to someone or something that was lost and forgotten by Western metaphysics... and needs to be recalled again' (p.3). It 'signals a movement of return to what I call a primordial wager, to an inaugural instant of reckoning at the root of belief. It marks a reopening of that space where we are free to choose between faith or nonfaith. As such, anatheism is about the option of retrieved belief....Anatheism, in short, is an invitation to revisit what might be termed a primary scene of religion; the encounter with a radical Stranger who we choose, or don't choose, to call God' (p. 7).

Kearney argues that one of the most potent ways of returning us to the moment of anatheistic wager is via the work of poets, writers and artists; those whose dramatic readings and interpretations allow us to enter imaginatively into the lives of people and events portrayed in biblical or other sacred texts and which offer the possibility of a return to the sacred moment of choice. The attempt to reposition faith in the light of our disenchantment with religious dogma and ideology is clearly part of Tóibín's artistic project in The Testament of Mary, where his re-visioning of Mary's life distances us from our traditional beliefs whilst at the same time offering us the potential for faith of a different order. Fiction's capacity to bring into being imagined worlds is, of course, profoundly counterfactual. To read fictional literature is to believe, albeit provisionally, in the existence of characters and situations that we know don't exist. In Tóibín's story, we are asked to believe in the possible existence of his version of Mary and her account of events. While we are taken through her story, we believe 'as if' she existed in just the same way 'as' believers endorse the canonical account of her life in the Bible. It is by juxtaposing his hypothetical account of Mary's life with the familiar account that he knows his readers hold that Tóibín not only offers us a Mary who wrestles with the putative divinity of her son, he allows us, while we read, to defer questions of belief and unbelief and identify with his version of Mary 'as if' it were true. We have been given poetic licence to suspend traditional religious belief, and accept 'in good faith' the very different version of events with which we are presented and which allow us to imagine otherwise.

But by blurring the distinction between faith and fiction Tóibín also allows us to read Mary's story 'as if' it were the Bible. Of course, the mimetic function of fiction releases possible worlds of belief and action that differ substantially from the claims to authority and universality made by the Bible. Stories from scripture cannot be read simply for the purposes of entertainment or make-believe; they point to an inner secret or hidden meaning which is conveyed, in part at least, by the very particular language deployed. Auerbach's (1953) distinction between classical literature and the Bible points out that biblical language is deliberately brief and sparse, concerned with conveying only the decisive elements of a sacred narrative without the addition of superfluous detail. It is, as 
the King James version of the Bible perhaps best demonstrates, language at its most majestic; language making a claim to ultimate authority and truth. By contrast, Tóibín's Mary tells her story in language that is simple, rhythmic and repetitive: language that is very different from the one being prepared for the Gospel account of events. Recall that Tóibín's Mary is illiterate. Her words are not freighted with a background of concealed, sacred significance requiring theological interpretation. Rather, she uses words that are colloquial, informal, ordinary, maternal. Yet by offering the firstperson perspective of someone commenting on events privileged by sacred texts, Tóibín ensures that Mary's fictive testimony competes with the testimony of the Bible to claim a similarly compelling authority.

But if the fictive 'as if' enables us to read Mary's version of events 'as if' it were the Bible, it also enables us to think of the Bible 'as if' it were fiction: 'as if' imaginative story rather than 'as' sacred text. For just as Fra Angelico's artistic vision of the Annunciation gave his fellow monks imaginative free rein to fill in the details of the story, so too Tóibín's story points to the necessary role of the imagination in all religious belief. Certainly, it could be argued that without imaginative reinterpretations, the meaning of canonical texts becomes fixed or static, losing the vitality and immediacy required if they are to speak freshly to new groups and generations. This interpretative or fictive element in faith is located by Kearney (2010) in the cultural shift from ancient religious rites to their symbolic representation in the Greek tragedies. In these great early dramas, literal religious or sacrificial rituals were transmuted into powerful narratives during which the audience suspended their literal belief in the gods and heroes in favour of something figural or metaphorical. Such mimetic re-creation aimed at opening up a gap, a breach, between events and their dramatic retelling that not only ensured a certain distance or perspective from which to view the unfolding characters and situation, but also ensured empathy with those whose suffering was portrayed in the drama. Kearney suggests that the gap opened up by the fictional rendering of events transports us to the future anterior, to the undecidable space of what might have been. It is here, gripped by a story that demands emotional as well as spiritual engagement, that we are returned to the originary moment of wager where faith is once again a choice.

It is surely no-coincidence that Tóibín himself has described how his idea for The Testament of Mary had its basis in an imagined visit by the disciple John to the theatre in Ephesus. He suggests that John was struggling to write his gospel and wanted to find the most powerful way of conveying the events surrounding Jesus's crucifixion and death. The theatre, Tóibín suggests, was showing a play by Aeschylus, and it was this that caught John's imagination: '..and then what he saw in the theatre lifted him out of his dilemma. His imagination soared with the crowd around him as, in some play that has been lost to us, he watched the enactment of a grieving woman imploring, crying out, and gaining power from her own voice. And then he watched someone seeming to return from the dead. The effect on the crowd around him and on himself was tremendous. Thus he found out what to do when he began to write his Gospel... He began to see the influence his writing might have....' (Daily Telegraph, April 2014). This is, I think, an astonishing piece of imagination - or rather, of imagined imagination - where Tóibín speculates that the inspiration for St John's account of the crucifixion, and his reasons for deciding to place Mary at the foot of the cross, might been inspired by watching a play, a Greek tragedy: and how John's gospel story, soon to become the cornerstone of the new Christian religion, could itself have been derived from a piece of dramatic fiction. Rather than merely hollowing out religious texts in favour of an empty secularism, then, I see Tóibín's Testament of Mary demonstrating the way we as readers and believers come to have faith in the power of story, 
the way stories inhabit us and become woven into the fabric of our lives. By re-telling and reimagining Mary's story, Tóibín shows how the creative space of fiction can work to break these old stories open, acting as the cornerstone of a second faith that is different from our first, 'naïve' faith; one that allows us the freedom to imagine otherwise, to tell another story - the story of how things might have been.

\section{The wager of faith in psychoanalysis.}

What can we as therapists learn from Tóibín's artistic re-visioning of the Gospel? What are the implications of the wager of faith in fiction for how we might understand any notion of faith in psychoanalysis? Indeed, how might we understand 'faith' in the first place? In order to sharpen the contours of these complex questions, we might do well to start with Treanor's (2010) discussion of Kearney's anatheism in which he attempts to distinguish between faith, belief and knowledge. To know something, he suggests, requires evidence or credentials that establish our knowledge as 'true'; whilst to believe something is to accept it without the need for any such verification. Faith, however, is different. It is a particular type of belief that includes a readiness to commit, to act: a wager on which everything is staked. 'The distinction between belief and knowledge is epistemic', he writes, 'and has to do with how certain we are about a given proposition, while the difference between belief and faith is existential [...] having to do with our commitment to live in the light of a certain proposition' (p. 549). In this sense, as Treanor argues, faith may be considered different from knowledge in terms of what it is possible to verify, whereas faith may be considered different from belief in terms of what we are prepared to do: the extent to which we are committed, willing and able to take a 'leap of faith' that could change our lives.

While it may be difficult to sustain Treanor's separation of the epistemological and the existential aspects of faith - they are surely two sides of the same anatheistic wager - the distinction may be a useful starting point for our discussion. For Kearney (2010) seems particularly sympathetic to a faith that is characterised by a whole-hearted, imaginative and engaged orientation, not simply one that relies on proof or evidence. His notion of anatheism is primarily concerned with articulating a faith that rests more on transformation than on calculation. Tóibín, too, in his reworking of Mary's life, points us towards the transformative potential of literature, where the fictive 'as if' of poetic licence vividly engages the reader in an existential rather than epistemological wager of faith. If we take Fra Angelico's painting of the Annunciation as analogy, we might imagine Tóibín's message - and those of other writers and artists - as akin to the beating of wings at the door heralding the arrival of the angel Gabriel; and the annunciatory potential of the creative work as awaiting entrance in the form of assent from an individual willing to hear what they might have to say.

The existential wager here pre-eminently rests on the stance we take up in the presence of the creative work of art, the spirit in which we respond to the provocation of its message. The issue of reception is central. Is the message something to be accepted and welcomed - or refused and repudiated? There seems to be a link here, as Kearney (2010) notes, with ancient notions of hospitality. To offer hospitality to the Stranger is always to encounter the unfamiliar and to welcome what is new and different into our home or lifeworld. But hospitality does not only refer to concrete interactions with those we do not know. It refers, in metaphorical form, to a kind of attentiveness to 'otherness' that includes a receptivity to that which is mystical or holy, and an openness to what is most unfamiliar or 'foreign' within ourselves and those with whom we come into relationship. For 
this reason, as Levinas (1969) intimates, the figure of the Stranger is always to be considered sacred by virtue of embodying something 'other', something different, something in excess of that which we can contain within ourselves. The etymology of the term hospitality, of course, is linked to two Latin words, the first of which, hostis, carries the dual meaning of both host but also stranger or enemy. The host is the one who lays down his or her weapons and welcomes the Stranger in a mutual relationship of trust. But hospitality is linked to a second, related term hospes, which contains within it the root word pot, meaning master, from which we get potestas or power. Hospitality, then, also contains within in the notion of power, where the host has the power to welcome or refuse foreigners or strangers into the home. Hospitality is thus a term of considerable ambiguity; it is never a given, never guaranteed, and our response to the Stranger, our willingness to grant him or her admission to our home, ultimately entails an existential wager of faith: that the other will turn out to be someone to whom we might want to listen, who is worth receiving - rather than somebody who is merely exploitative, greedy or murderous.

The literary critic George Steiner (1989) argues for just such a spirit of hospitality when we are confronted with the message of writers and artists who try to give otherness creative form. Our attitude towards of the work of art, he suggests, requires a kind of an inner receptiveness or openness that I take to be constitutive of Kearney's inaugural encounter: a rendezvous with alterity in which we do not read the novel so much as encounter it; in which we do not look at the painting so much as relate to it; and in which we do not listen to the song so much as feel it in our bones. Receiving the work of art in this way entails accepting its message 'in good faith', the kind of faith that is prior to any knowledge or calculation. It speaks of a relationship that St. Anselm characterises as fides quaerens intellectum, or 'faith seeking knowledge'. It is akin to Derrida's (2000) notion of 'absolute hospitality', in which love of the host for the guest precedes and surpasses whatever we may come to know of him or her. Derrida's (2000) messianic hospitality, a hospitality that is always 'to come', 'requires that I open up my home and that I give not only to the foreigner, but to the absolute, unknown, anonymous other, and that I give place to them, that I let them come, that I let them arrive, and take place in the place I offer them, without asking of them either reciprocity (entering into a pact) or even their names' (p. 24). In relation to the novel, the painting or the song, such hospitality is constituted by an existential moment of choice requiring a cordial openmindedness; a generous willingness to hear and engage with what the artist has to say in much the same way as we would be willing to hear the words of the Stranger we have invited into our home. Of course, not all strangers turn out to be divine. Literary, artistic or musical works are not all of equal worth, nor are they all equally accessible. Some may be formulated in ways that are remote or abstruse, and hospitality to the artist's message may yet prove ill-founded if it turns out to be unintelligible or unrealizable. Disappointment and disillusion are necessary risks we must take, for 'without the gamble on welcome', says Steiner (1989), 'no door can be opened when freedom knocks' (p. 156).

Perhaps these ideas about our reception of the artistic message can help to think freshly about the reception of alterity within psychoanalysis. For when we read Tóibín's story, just as when we see or listen to what the artist or composer has to say, '[w] seek to make out' as Steiner (1989) says, 'the intelligibility, the claims upon us of his gestures and discourse. We realize full well that our comprehension, even as it deepens into intimacy, most particularly where it deepens into intimacy, will remain partial, fragmentary, subject to error and to revaluation' (p. 176). The excess, the surplus, the sheer otherness that inheres within the novel or work of art finds its correlate in the 
alterity of the other whom we encounter within psychoanalysis, an otherness that will always exceed our capacity to know or penetrate its enigmatic core. In both cases, hospitality towards the other requires a conjectural, provisional sensibility that maintains a certain 'negative capability' entailing a praxis of expectant waiting: a 'gamble on welcome', as Steiner (1989) says, that precludes any rush to conviction or certainty.

There is surprisingly little in the psychoanalytic literature that specifically addresses this 'gamble on welcome'. A notable exception is Pascal's wager on the existence of God that is discussed extensively by Lacan (2006a; 2006b) in Seminars XIII and XVI. Bearing in mind Treanor's (2010) distinction between the epistemological and existential aspects of faith, however, I see Lacan's deployment of Pascal principally as a means of indexing a calculative, epistemological wager based on what we can or cannot know of the symbolic 'Other'. Here, I prefer to follow Kearney in privileging the existential issue of what we do in the face of alterity, our willingness to engage wholeheartedly with otherness. Writers such as Eigen (1999), for example, understand the patient's faith as a quest for emotional intensity and authenticity within the psychoanalytic relationship: ' $a$ way of experiencing that is undertaken with one's whole being, all out, 'with all one's heart, with all one's soul, and with all one's might' (p. 3). These qualities of passion and commitment are also discussed by Ghent (1999), who seeks to develop an understanding of the role of emotional surrender in promoting a radical transformation of the self.

The existential wager within psychoanalysis is perhaps best characterised in Winnicott's (1971) seminal paper 'The Use of an Object'. It is exceptionally difficult, of course, to do justice to the richness and density of Winnicott's thinking in any brief summary. But reading his paper in the light of The Testament of Mary may help to clarify the aleatory nature of faith I am trying to elucidate here. For just as Tóibín returns his readers to a vivid, fictive space in which the choice of faith is once again a reality, so too, suggests Winnicott, is the patient in psychoanalysis returned to an illusory space of transitional experiencing in which there is an inaugural encounter with otherness. It is within this liminal area of transitional space that Winnicott outlines developmental processes that

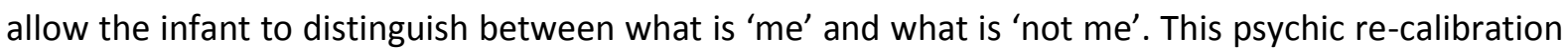
enables an awareness of the other beyond the infant's omnipotent control. Crucially, however, otherness is never assured. It subsists not in demonstrable certainties, but rather in what I am calling here an existential, lived wager that its presence can and will be maintained despite the risk of its liability to loss and change. In his well-known discussion of the shift from object-relating to objectusage, Winnicott (1971) points out that: 'This thing that there is in between relating and use is the subject's placing of the object outside the area of the subject's omnipotent control; that is the subject's perception of the object as an external phenomenon, not a projective entity, in fact recognition of it as an entity it its own right' (p. 105). Discussing the astonishingly delicate and complex psychic negotiation that Winnicott goes on to imagine would take me beyond the scope of the present paper. What is significant here, however, is that the object's very alterity sponsors destructive attacks in which we might say the subject wagers all on the existence and surviving presence of the other. The stakes are high, for 'the experience depends', warns WInnicott bleakly, 'on the object's capacity to survive' (p. 107). There is always the risk that the object may simply collapse, degrade or become useless, failing to break free of the subject's omnipotent projective mechanisms. In this encounter with otherness, where the subject is gambling on 'finding externality itself' (p. 107), there can be no foregone conclusion, no certain outcome. Hospitality operates on the very knife-edge of hostility. Ghent (1999) vividly describes the phenomenology of the infant's lived 
experience in the following terms: 'One might imagine the subject saying to the object, "I went all out, completely vulnerable, in the faith that someone was out there - and it turned out to be true, as I could only have known by destroying you with all my might and yet here you are. I love you."' (p. 214). I want to suggest that the full-blooded, 'all out' quality of commitment highlighted by Ghent indexes a faith in alterity that lies prior to any knowledge or understanding. Indeed, in 'creating' the object through destructive attack, the baby inaugurates, in fantasy, the very existence of an otherness which only later, and with some difficulty, it may come partially to know. We might say, going back to St. Anselm, that the baby's 'all out' love is a form of 'faith seeking knowledge'. It constitutes what I take to be the central psychoanalytic wager of faith in alterity itself: an existential - not calculative - wager that must be lived and repeated many times over before the resilience and survival of otherness can be felt, trusted and known.

In such a brief outline, I have inevitably glossed over many subtleties in Winnicott's thinking that bear much deeper discussion. The schematic framework above may be sufficient, however, to index at least some of the psychic co-ordinates at play within the psychoanalytic wager of faith. Perhaps it also serves to illuminate an issue with more weighty implications: how survival of the object could be thought of as symbolic of the survival of that inner presence of alterity many mystical traditions see as the basis of faith. Psychoanalysis has traditionally fought shy of such claims, preferring to assign our understanding of alterity firmly to the unconscious. ${ }^{1}$ Yet if we imagine, along with Winnicott, that our early, illusory experiences within transitional space lie at the heart of our adult capacity to enjoy and make use of the fictive 'as if' space within literature, drama, art and music, then we might also imagine these developmental experiences as paving a psychic path to our adult search for the sacred, however we conceive it. Indeed, we might remember that Winnicott (1971) regards the potential space between mother and baby 'as sacred to the individual' (p.121). It is possible, then, that our capacity to 'imagine otherwise' - a capacity to which Tóibín himself so richly attests - constitutes an umbilical cord linking us to the dimension of transcendence; to an originary experience of alterity or otherness that is more than we can ever encompass. In saying this, I do not mean to return us to religious faith any more than I think Tóibín does, though that is, of course, one of the choices open to us at the moment of wager. Rather, I am suggesting that religious faith may be woven from the same psychic yarn as the one spun early on in life; the one that knits otherness so hospitably within the self that it takes up residence as an inner, unseen guest, in whose presence we may come to have the capacity, as Winnicott later suggests, to be alone.

\section{Testimony: the psychoanalytic wager}

The capacity to be alone, to bear solitude, is the necessary precondition for the act of testifying or bearing witness to one's truth. Felman (1992) writes: 'To bear witness is to bear the solitude of a responsibility, and to bear the responsibility, precisely, of that solitude' (p.3). Tóibín's Mary is testifying to what she herself has seen and heard and it is clear that, despite the pressure from her

\footnotetext{
${ }^{1}$ However, in a footnote to his paper, Ghent (1999) cites Rycroft (1966) who 'observed that 'there would seem to be no necessary incompatibility between psychoanalysis and those religious formulations which locate God within the self. One could, indeed, argue that Freud's Id (and even more Groddeck's It), the impersonal force within which is both the core of oneself and yet not oneself, and from which in illness one becomes alienated, is a secular formulation of the insight which makes religious people believe in an immanent God' (p. 215).
} 
guardians, she will not give false witness: 'Just as I cannot breathe the breath of another or help the heart of someone else to beat...I cannot say more than I can say' (p. 4). By taking responsibility for speaking her truth, a truth that she and she alone can speak, Mary is placed in a uniquely precarious situation.

But so too is the patient in psychoanalysis. In offering an account of his or her life to the analyst who listens, the patient is, like Mary, in the unique situation of bearing witness to his or her own story. Yet just as we cannot know the 'truth' of Tóibín's version of Mary's life, so too we cannot know the 'truth' of our own. For if, as Freud (1923) suggests, our subjectivity is constituted by the presence of the other within, if the introduction of alterity into the ego precedes the formation of a self that may, one day, come to bear witness to its own personal truth, then any story that we subsequently come to tell about our lives is necessarily incomplete, estranged from itself from the outset. Indeed, psychoanalysis is predicated on the presence of an unconscious that alienates us from the conditions of our emergence as subjects. We are 'fearfully and wonderfully made', sings the psalmist in the King James Bible; we are shaped in ways we cannot know by the other who becomes the basis of a self and an unconscious we call our own but of which we are radically dispossessed. In this sense, the patient in psychoanalysis is asked to bear the responsibility of being witness to a truth that can never be owned, a truth to which he or she must constantly testify yet which is forever unavailable. 'My account of myself', writes Butler (2005) 'is partial, haunted by that for which I can devise no definitive story' (p. 40). And yet, as Tóibín's imaginative retelling of Mary's life shows, the undecidability of our account, its radical unknowability, does not necessarily refute the validity of any story we narrate though it may offer the potential for breaking it open. Its very undecidability is what opens up a fictive space that allows us the freedom to imagine the story otherwise and permits faith in the possibility of a different life - a different story - to thereby emerge. It is this space that returns us to the inaugural moment of choice where we are able to choose this story rather than another to be the one we allow to inhabit and nourish us. Perhaps this is precisely the 'gamble on welcome', the existential wager of faith we must risk if we are to undertake a psychoanalysis.

By way of concluding, let us return to the end of Tóibín's story. We find Mary back at home in Ephesus, listening to her guardians who are once again attempting to explain to her the importance of what has happened, of how her son will change the world. But now they insist on telling her about the circumstances of Jesus's conception; a story that we as readers know will become the celebrated biblical version of the Annunciation, the one so vividly imagined - and re-imagined - by Fra Angelico and thousands of artists after him. But Mary will not listen. 'I know what happened' she tells us. "I know that my own happiness in those first months when I was with child felt strange and special, that I lived in way that felt different... Later, I learned that this is how we all prepare ourselves to give birth and to nurture, that it comes from the body itself and makes its way into the spirit and it does not seem ordinary' (p. 100).

Mary's faith, we learn by the end of this remarkable book, lies not in the new God of Christianity, nor in any suggestion that her son Jesus was the Son of God. Her faith is the faith of a mother who believes only in what she remembers of her child. And so, instead of converting to the story being created by the disciples about Jesus's divinity, Mary's faith rests on the story she continues to tell herself about the human relationship she had with her son. Rather than believing in the inner, unseen presence of a deity, Mary movingly recalls the inner, unseen presence of her unborn child, a physical presence that she remembers 'felt strange and special'. The ordinary, yet extraordinary, 
presence of otherness within is seamlessly transferred by Tóibín from the domain of the divine to the domain of the secular, where the simple story of a baby growing within the womb of its mother is imbued with the quality of the sacred. It is to these homely environs that Tóibín returns us, gently hinting - as does Winnicott too - that it is within the folds of the other that the vectors of faith are to be found.

\section{References}

Auerbach, F. (1953). Mimesis. The Representation of Reality in Western Literature. Trans. Willard R. Trask, Princeton University Press.

Bion, W. (1970). Attention and Interpretation. London: Tavistock.

Butler, J. (2005). Giving An Account of Oneself. NY: Fordham University Press.

Caputo, J. (2006). The Weakness of God: a Theology of the Event. Bloomington, IN: Indiana University Press.

Derrida, J. (1995). The Gift Of Death. Chicago: The University of Chicago Press.

Derrida, J. (2000). Of hospitality (translated by R. Bowlby). Palo Alto, CA: Stanford University Press.

Eigen, M. (1999). The Area of Faith in Winnicott, Lacan and Lacan. In: Relational psychoanalysis: The emergence of a tradition. Eds: Mitchell, S. and Aron, L. (1999), pp. 211-242. Hillsdale, NJ: The Analytic Press.

Emerson, R. W. (1850). Representative Men: Seven Lectures. US: Belknap Press (1996), p. 101.

Felman, S. (1992). Education and Crisis, or the Vicissitudes of Teaching. In: Felman, S. and Laub, D. (1992). Testimony. Crises of Witnessing in Literature, Psychoanalysis and History. NY: Routledge.

Felman, S. (1977). To Open the Question. Yale French Studies, 55-56, 5-10.

Freud, S. (1927) The Future of an Illusion. In: J. Strachey (Ed. and Trans.), The Standard Edition of the Complete Psychological Works of Sigmund Freud, Vol. 21, pp. 5-55. London: Hogarth.

Freud, S. (1923) The Ego and the Id. In: J. Strachey (Ed. and Trans), The Standard Edition of the Complete Psychological Works of Sigmund Freud, Vol. 19, pp. 1-66. London: Hogarth.

Ghent, E. (1999). Masochism, submission, surrender: Masochism as a perversion of surrender. In: Relational psychoanalysis: The emergence of a tradition. Eds: Mitchell, S. and Aron, L. (1999), pp. 211-242. Hillsdale, NJ: The Analytic Press.

Hodge, B. (2006). 'The Goddess Tour: spiritual tourism/post-modern pilgrimage in search of Atlantis. In: The Politics of Contemporary Enchantment, Eds. Lynne Hume and Kathleen McPhillips, pp. 22-40. London: Routledge.

Hood, W. (1993). Fra Angelico at San Marco. New Haven: Yale University Press. 
Kearney, R. (2015). Anatheism. Returning to God after God. New York: Columbia University Press:

Kearney, R. (2001). The God Who May Be. A Hermeneutics of Religion. Bloomington, IN: Indiana University Press.

Lacan, J.(2006a). Le Séminaire. Livre XIII: L'objet de la psychanalyse. Ed. Michel Roussan. Unpublished.

Lacan, J. (2006b). Le Séminaire. Livre XVI: D'un Autre à l'autre. Ed. Jacques-Alain Miller. Paris: Seuil. Lloyd, D. and White, D. (1998). Fra Angelico. Phaidon Press; 2nd Revised edition.

Neri, C. (2005) What is the function of faith and trust in psychoanalysis? The International Journal of Psychoanalysis, 86:1, 79-97.

Ostow, M. (1995). Normative religion versus illusion. In M. Ostow, Ed., Ultimate Intimacy: The psychodynamics of Jewish mysticism. Madison, Conn.: International Universities Press.

Rieff, P. (1966). The Triumph of the Therapeutic. Uses of Faith after Freud. New York: Harper and Rowe.

Rushdie, S. (1988). The Satanic Verses. London: Viking, Penguin.

Safran, J. (2006) The Relational Unconscious, the Enchanted Interior, and the Return of the Repressed, Contemporary Psychoanalysis, 42:3, 393-412.

Safran, J. (1999) Faith, Despair, Will, and the Paradox of Acceptance. Contemporary Psychoanalysis, $35: 1,5-23$.

Sorenson, R. L. (2004). Minding spirituality. Hillsdale NJ: Analytic Press.

Starr, K. (2008). Faith as the Fulcrum of Psychic Change: Metaphors of Transformation in Jewish Mysticism and Psychoanalysis. Psychoanalytic Dialogues, 18:2, 203-229.

Steiner, G. (1989). Real Presences. Chicago: University of Chicago Press.

Spezzano, C. and Gargioulo, G. (2013). Soul on the Couch. Spirituality, Religion and Morality in Contemporary Psychoanalysis. New York: Routledge.

Sweetman, B. (2011) A Gabriel Marcel Reader. St. Augustine's Press: Indiana.

Treanor, B. (2010). The Anatheistic Wager: Faith After Faith. Religion and the Arts, 14: 547-560.

Winnicott, D. (1971). Playing and Reality. London: Penguin.

Warner, M. (2000). Alone of all her sex. London: Vintage.

Zornberg, A. (1995). The beginning of desire: Reflections on Genesis. New York: Doubleday.

Zornberg, A. (2002). The particulars of rapture. New York: Doubleday. 